\title{
SETTING UP A SMALL BUSINESS IN ALBANIA: RETURN MIGRATION AND ENTREPRENEURSHIP
}

\author{
Kalie Kerpaci \\ Faculty of Education, Aleksander Moisiu University of Durres \\ Lucie Miloti 1, Allias, 1001, Tirana: Albania \\ kkerpaci@gmail.com
}

\begin{abstract}
In this paper, I deal with the phenomenon of Albanian return migration. I focus on the category of returned migrants from Greece, who own a small business in Tirana, the capital of Albania. The aim of the research is to explore the circumstances under which the migrants decided to return and set up a business. I try to analyze the reasons they engaged in entrepreneurial activities through the necessity-opportunity entrepreneurship approach. Some became entrepreneurs out of necessity to avoid unemployment; others because of business opportunities. Within this last group of opportunity-seizing returned migrants, there are some who planned their return and intended to set up a business before migrating. Their objectives in Greece were to save money and gain the know-how enabling them to start and run a business back in Albania.
\end{abstract}

Keywords: migrant entrepreneurship, motivation, return migration.

\section{Introduction}

The primary motives underpinning decisions to migrate to more-developed countries usually relate to poverty, economic crises or war. Migration plays a significant role in the economic growth of countries of destination - because of the increase in production capacity and aggregate demand for goods and services (OECD, 2014); and countries of origin - thanks to remittances migrants send back to their families at regular intervals. The countries of origin also benefit economically where a return ultimately takes place, as migrants in this category are considered important agents of social and economic change (Cassarino, 2004). They bring back their experiences from other countries, new ideas and ways of thinking, their savings and entrepreneurial drive (Levitt, 1998; Turner \& Kleist, 2013, p.192).

For the above reasons, there is a growing interest on the part of origin in promoting domestic policies that attract migrants to return. This, has now been documented by many researchers (Cohen, 2009; Tsuda, 2010; Boccagni, 2011; Ho, 2011; Åkesson \& Eriksson-Baaz, 2015; Kerpaci \& Kuka, 2019; Sinatti, 2019). Policies pursued include incentives designed to attract specific groups of migrants (e.g. those intending to invest their savings and become entrepreneurs), by offering tax breaks and better access to schooling and health services (Sinatti, 2019).

The tendency of returned migrants to opt for entrepreneurial activity is likewise demonstrated in a plethora of studies (Arif \& Irfan, 1997; Ilahi, 1999; McCormick \& Wahba, 2001; Dustmann \& 
Kirchkamp, 2002; Mesnard, 2004; Black \& Castaldo, 2009; Gubert \& Nordman, 2011; Kilic, Carletto, Davis \& Zezza, 2009; Lianos \& Pseiridis, 2009; Piracha \& Vadean, 2010; Démurger \& Xu, 2011). While each of these shed further light on the connection between return migration and entrepreneurship, as well as the impact exerted on the economy of the country of origin, there was no exploration in depth of the circumstances under which returned migrants decided to set up a business in their country or move their business there from the country of destination.

The focus of this paper is therefore on the motives that pushed or pulled the Albanian migrants returning from Greece to invest their money in setting up a small business in Albania. More specifically, the objective is to analyse the conditions under which these people returned and decided to set up a business in Tirana, Albania's capital city, through the lens of the necessity-opportunity entrepreneurship approach, also referred to as 'pull-push' motivations (Reynolds, Camp, Bygrave, Autio \& Hay, 2002; Maritz, 2004; Smallbone \& Welter, 2004; Perunovic, 2005; Harding et al., 2006; Minniti, Bygrave \& Autio, 2006; Hessels, van Gelderen \& Thurik, 2008; Desai, 2009). The first part of this approach - necessity - is seen as a strategy for survival. Individuals are pushed into entrepreneurship thanks to a variety of structural factors, such as unemployment, lack of convenient employment alternatives, and poverty (Schumpeter, 1974; Minniti et al., 2006). Entrepreneurship in fact becomes a means for the individuals involved to escape these last two consequences, leaving their engagement in such activities as explicable in terms of necessity.

The second aspect here - opportunity - relates to individuals pulled into entrepreneurship on account of their desire to become independent of higher authority, increase their income, as well as improve their social or economic status and standing (Kolvereid, 1996; Smallbone \& Welter, 2004; Minniti et al., 2006). The emphasis here is thus on the freedom of the individual to choose to become an entrepreneur; rather than on necessity. Opportunity-driven individuals who made such a choice are shown to manifest great ability when it comes to recognising opportunities on a given market (Baron, 2004). Prior knowledge and experience are important in this (Shane, 2000; Shepherd \& DeTienne, 2005; Arentz, Sautet \& Storr, 2013), as are such psychological factors as creativity, motivation, and specificity of goals (Hills, Shrader \& Lumpkin, 1999; Krueger, 2005).

\section{Albanian migration and return migration}

Albanian migration itself was seen as a survival strategy initially (De Soto, Gordon, Gedeshi \& Sinoimeri, 2002; Kule, Mançellari, Papapanagos, Qirici \& Sanfey, 2002; King \& Vullnetari, 2003). When communism fell at the beginning of the 1990s, Albanians were motivated to leave the country in search of a better life in the West. This was primarily a reflection of political and economic instability at home, along with a weak legal system and high levels of unemployment (Barjaba, 2004). There was also a small(er) number of migrants that left Albania out of a curiosity to explore the West, given its status as a world very different from their own (Kerpaci, 2019).

In most cases, migration was regarded as a temporary solution, with many of those involved planning their return even prior to migrating. The clear intention in such cases was to save money, send remittances to improve the living conditions of any family back home (Nicholson, 2001; Labrianidis \& Lyberaki, 2004, p.90), invest in profitable activities (Puri \& Ritzema, 1999, p.18; Nicholson, 2001), or await a suitable job opportunity arising in Albania while continuing to work abroad (Labrianidis \& Hatziprokopiou, 2005).

Albanian migrants maintained strong ties with their home country. Migrants living and working in Greece, especially (where distance was not a major obstacle), visited Albania regularly during 
summer vacations, Easter or Christmas holidays. Apart from wanting to be close to their relatives, these visits functioned as opportunities for market research in regard to investment or employment opportunities. People involved sought to have some kind of financial security in the event of their deciding to return to Albania (Michail, 2009).

Equally, legalisation problems, as well as initial employment instability, made long-term planning from within Greek society a near-impossibility. Indeed, various studies on the economic integration of Albanian migrants into the Greek labour market make it clear that most males worked in construction, agriculture, industry and tourism, while women mainly tended to work as domestic helpers (losifides\& King, 1998; Hatziprokopiou, 2003; Baldwin-Edwards, 2004).

According to Labrianidis and Lyberakis (2001) and Hatziprokopiou (2006ab), the beginning of Albanian migrants' experience with migration to Greece saw them doing unskilled jobs in bad working conditions, and subject to exploitation by host-country employers. In most cases, people had no option but to accept work under these circumstances. For, in line with a status as irregular migrants, those involved could not aspire to work in their professions, or in general to be selective as regards employment opportunities.

Beyond that was the matter of the image of Albanian migrants - as criminals (Tsoukala, 1999; Kourtovik, 2001; Pavlou, 2001; Vullnetari, 2007; Michail, 2009), 'as the embodiment of poverty and backwardness, and as the invader and enemy' (Kapllani \& Mai, 2005). This was seen as promoted by the Greek media first and foremost, while it also entailed notorious police operations arresting and repatriating illegal migrants that became known widely as skoupa, i.e. 'the broom' (Pavlou, 2001; Triandafyllidou, 2002; Jordan, Stråth \& Triandafyllidou, 2003; Kerpaci, 2019). Naturally, this had a negative impact on migrants' (possibilities of) social and economic integration within Greek society.

For their part, Michail (2009) and Kokkali (2011) noted how Albanians' incorporation into the Greek labour market was apparently a (more) complex issue of inclusion and exclusion. While there was no actual full exclusion from either formal or informal markets, there was no achievement of full inclusion either. This reflected a complex, decades-long 'love-hate relationship' between Greeks and Albanians (Kerpaci, 2007). While Greeks indeed trusted Albanians to work in their homes, hired them at their farms and businesses, they did not want them as neighbours, avoided socialising in the same places, and even forbade their children to marry Albanians.

These attitudes changed gradually, with the social integration of Albanian migrants first facilitated by legalisation (Kerpaci, 2007, 2019), this also improving the position on the labour market (Hatziprokopiou, 2006ab; Kerpaci, 2019), given the way in which better employment opportunities might now be taken advantage of (Baldwin-Edwards, 2004, p.54). According to Kasimis \& Papadopoulos (2012, p.294-295), in these circumstances, Albanian migrants in Greece were able to show the fastest career advancement relative to other migrant groups (followed by Bulgarians and Romanians). However, as this still did not denote job profiles matching either qualifications or experience gained in Albania, there remained a significant reason for some migrants to (seek to) return to their home country (Kerpaci \& Kuka, 2019). Furthermore, there was no doubt that Albanians continued to earn significantly smaller amounts than natives of Greece doing the same work (Kokkali, 2011), while such career advancement as might be possible was mainly found to be a chance for men, as opposed to women. Given women's usual work as domestic helpers, that lack of any opportunities for advancement in their case was clear (Kerpaci, 2019).

Thus, although the overall work experience of Albanian migrants definitely improved over time, with increasing apparent integration into Greek society, the ongoing feeling remained one of being both marginalised and discriminated against (Vullnetari \& King, 2011). 
Some studies show how migrants returning to Albania were quite likely to pursue self-employment, rather than working for others (Nicholson, 2002; Kilic et al., 2009; Piracha \& Vadean, 2010; Hausmann \& Nedelkoska, 2017). Other related research (Nicholson, 2001, 2002; Labrianidis \& Hatziprokopiou, 2005) supports a linked contention that returned migrants' work experience in countries of destination proved useful to establishment at home of the same type of business that had been worked in and provided expertise while those same people were abroad. Not always were they successful in their endeavours, however - as the economic and human capital accumulated by migrants while on migration did not always suffice to ensure success in business back home.

In the first place, the Albania returned to now did not prove the same as the version remembered from times prior to migration. Significant change had indeed occurred during the years of absence, with this being tantamount to a new environment in some cases - necessitating a reintegration process among those returned migrants. And that reintegration - whether economic, social, or political - could prove a difficult process. Ways had to be found to deal with everyday corruption, a poor economic and employment environment, and a lack of physical and social infrastructure (King \& Vullnetari, 2003; Nicholson, 2004; Labrianidis \& Hatziprokopiou, 2005; Michail, 2009, 2013; Vathi, 2011; Vathi \& King, 2011; Vullnetari, 2012, INSTAT, IOM, 2014; Kerpaci \& Kuka, 2019). People might also have lost their networks of friends and colleagues in the interim period (Kerpaci, 2019; Kerpaci \& Kuka, 2019). Lack of a quality education system and health services were also significant problems encountered by returned migrants in their everyday lives back in Albania (Gedeshi \& King, 2018; Kerpaci, 2019; Kerpaci \& Kuka, 2019).

In response to these challenges, the Albanian government has tried to promote measures facilitating the return and reintegration of Albanian migrants. Although it continues to declare that it has developed relevant policies and programmes, including to achieve migrants' investment of their money in Albania, the observed outcomes have proved insignificant (Vullnetari, 2013). In practice, the government has not succeeded in either targeting migrants or implementing appropriate measures (Vullnetari, 2012; Kerpaci, 2019; Kerpaci \& Kuka, 2019). The study carried out by INSTAT and IOM (2014) shows that only $15 \%$ of returned migrants declared their return and registered at the migration counters set up by the government to provide assistance. A lack of knowledge about any effort by the Albanian government to supply assistance is also evident in research by Kerpaci and Kuka (2019) targeted at returned migrants from Greece.

\section{Methodology}

The work detailed here has seen me seek to provide ethnographic insight into the narratives of returned migrants, as I analyse their experiences of becoming entrepreneurs back in their home country of Albania. The basis is provided by 15 semi-structured interviews I ran with migrants ( 8 men and 7 women, referred to by pseudonyms), who returned from Greece and have opened small businesses in Tirana. Their ages range from 31 to 44 years. These people had lived and worked in Greece for considerable periods of time, ranging from 6 to 22 years; while their years of return to Albania were between 2004 and 2012. Most of the 15 were holders of degrees awarded by Albanian universities - which they had gained before migrating.

Interviews were conducted between 2013 and 2014, at locations chosen by the interviewees, with durations ranging from 1 to 2 hours. In practice, most returned migrants elected to have me interview them at their places of businesses, given the way in which I would enjoy first-hand the opportunity to see how the given business was functioning. 
Semi-structured interviews provide for a better understanding of the migration experience, and of the factors that pushed or pulled the migrants into entrepreneurial activity back in Albania. Interviews of this kind also have the flexibility to accommodate additional questions or a change of questions as they are in progress - in line with replies given and the general direction the conversation takes.

In the event, identification of the returned migrants-turned-entrepreneurs did not prove as easy as I had hoped, given similarities remaining between those involved and non-migrants (Ní Laoire, $2007,2008 \mathrm{ab}$ ). For this reason, I used the snowball technique to form the sample. This is based on the principal of networking, whereby I used connections from my years of studying and living in Greece to lead me to other returned migrants who would be willing to participate in this study.

\section{The decision to return and start a business in Tirana}

The engagement of Albanian returned migrants in entrepreneurial activity is influenced by a mixture of push and pull factors, thus in response to changing circumstances in both Greece and Albania. Migrants' decisions to set up businesses upon their return can be seen as either a way to escape unemployment or as opportunity to maximise earnings. There are also cases in which returned migrants had aspired to set up a business even before their migrations. In these people's cases, migration was viewed as a way to amass money and then return home.

The returned migrants decided to set up their businesses in Tirana, even though they did not actually hail from there. Before migrating, all had lived and worked in other Albanian cities. The reason for choosing Tirana to invest their savings now was mainly seen to reflect economic prospects offered. A survey carried out by INSTAT and IOM (2014, p.10) shows that returned migrants displayed a tendency to settle in prefectures where economic development had been significant (such as Tirana, as the region of strongest preference, followed by Vlorë, Elbasan, Fier, and Korçë (in the case of migrants returned from Greece); as well as Shkoder, Lezhë, Durrës and Dibër (for those returned from Italy). Other recent studies (Kerpaci, 2019; Kerpaci \& Kuka, 2019) have also reported Tirana as being viewed as metropolitan by returned migrants, with more employment or self-employment opportunities offered, a similar lifestyle to the one experienced in Greece, and better educational opportunities for students.

This study also highlights the significance of Tirana as the right place to return to and invest. Meri, 40 years old, who runs her own shoe shop, and Teli, 43 years old, the owner of a small sewing firm, said the following:

Tirana is the centre of the Albanian economy. (...) The money is here. (Meri)

My wife wanted to settle in Saranda [a coastal city in the south] because her parents live there. But I didn't agree. I thought that Tirana, as the most developed city in Albania, would be the best place for our business. In Saranda, there is life only during summer, whereas in Tirana everything is on the move. (Teli)

\section{Setting up a business out of necessity}

Many studies show that the choice to start a business made by migrants or returned migrants is defined by negative circumstances in the countries of origin and destination (Light, 2007; Locke \& 
Baum, 2007; Hessels et al., 2008; Aliaga-Isla \& Rialp, 2013; Lintner, 2018). These studies show how migrants choose to become business owners, given the lack of conventional job opportunities and the necessity to overcome financial problems. Many Albanian migrants lost their jobs as a result of the financial crisis that hit the Greek economy in 2008. Indeed, of all the migrant groups living in Greece, it was the Albanians that were most affected (Zografakis \& Kasimis, 2014, p.389). Their unemployment rate rose to $40 \%$ (INSTAT \& IOM, 2014).

Pier, 39 years old, and a returned migrant and owner of a small firm producing marble tombstones, lost his job in Athens in 2008, and remained unemployed for a long time. He worked for several years as a marble technician, but searched for any job he could find and did not show any preferences. Unfortunately, there was nothing significant for him. He discussed with his wife the possibility of returning to Albania to start a business similar to what he had experienced in Greece; and she agreed. Together, they decided it was best for Pier be the first to move back to Albania, only to be followed by the rest of the family at a later date. They needed to be sure that things with the new business would go well, before the decision to leave Greece permanently was taken.

I remained without a stable job in Athens for almost a year. I worked only four days a month. I was thinking of returning to Albania and setting up a small business (...). I had nothing to lose. I had the money. (...) [Also] in Tirana we had an apartment and, therefore, we didn't have to pay rent. I discussed the idea with my wife. She agreed. She was aware of the fact that her salary wasn't enough to cover our expenses in Athens. (...) We thought that it would be better if I moved there first, in order to see how things would go; then decide whether she and our children would join me in Albania. We didn't want to risk the futures of our children. (Pier)

Pier and a few other returned migrants (discussed in the following section) chose to invest in the same type of professional activity as had been the subject of their experience in Greece. In some cases, when a decision to return was taken unexpectedly (Dustmann \& Kirchkamp, 2002; Rapoport, 2002; Démurger \& Xu, 2011) and there was no significant experience in a specific job profile, the type of activity was selected by reference to informal market research carried out in Albania. Edi lost his job as a supervisor in a Greek vineyard thanks to the Greek debt crisis. He returned to Albania in 2012, but remained unemployed for about six months until he decided to start his own business. He said the following:

We had bought an apartment in Tirana and we didn't pay rent, but still we had other expenses. (...) We had to find a solution. Our savings were running out. (...) I was thinking what to do with the money that we accumulated in Greece. One day I was walking through the city [Tirana] and I observed that in one of the main streets there wasn't any shop selling sports shoes. I said to my wife: 'This is what we will do. We will open a shop with sports shoes'.

Some of the returned migrants started a business upon realising that the chances of being employed back in Albania were slim. Alba returned to Albania mainly because of nostalgia for home. She could not go on living in Greece in the face of continued longing for contact with close relatives. However, when back in Albania, she remained unemployed for almost eight months; so - taking advice from her brother - she ultimately decided to open a shop with women's clothing. She did not aspire to self-employment on account of her not knowing how to manage a business, but it still seemed the best solution at the time.

When I returned here [Tirana] I didn't think that it would be so difficult to find a job. My brother told me to open a shop with women's clothes. Many people in Albania did the same in order to escape unemployment. For me, becoming a shop manager was something that I didn't expect. In Greece I worked as a waitress, and I didn't have any idea of how to manage 
a small business. (...) But what could I do? I had to pay the bills. (...) So, I followed my brother's suggestion. (Alba)

Aldi returned to Albania because he had been unable to bring his family to Greece. Family unification was in fact a long, expensive, and bureaucratic procedure that not many migrants were able to complete (Baldwin-Edwards, 2002). For Aldi, another reason that prompted him to start a business in Albania (apart from unemployment) was the unacceptable treatment of employees by their managers.

[In Greece] I was doing different kinds of jobs, anything that was coming my way. (...) I couldn't continue living alone anymore. I needed stability in my life (...) and I decided to return. In Albania I stayed unemployed for over a year. I found work as a seller in a big company, but I didn't like the way the managers were treating us. Here in Albania, the managers or the business owners behave as if they are feeding their subordinates. So, I quit. I remained unemployed again for a while. Then I decided to start a business, an internet cafe. (...) But it didn't go well. I closed it after a year and a half. (Aldi)

Another business failure applied in the case of Niko. In Albania, he remained unemployed for over a year until he found a job in a firm that sold medical supplies. But he remained dissatisfied with the way the work was being managed. Eventually, his company went bankrupt and Niko was unemployed again subsequently - for more than two years. Among the many jobs he had done in Greece was bartending, so when a friend suggested he open a café-bar, he accepted immediately. The plans for their joint business were ambitious.

My friend and I invested our money in a café-bar, but after one year it turned out to be a bad choice. Our business failed. We opened it with the idea of expanding it, (...) rearranging space (...) as well as adding different snacks. But unfortunately, we needed permission for these changes, which we couldn't secure. They [City officials] demanded a lot of money in return. (Niko)

Indeed, corruption is one of the main barriers faced by returned migrants in Albania, be they entrepreneurs or not (Mai \& Paladini, 2013; Kerpaci \& Kuka, 2019). In the view of both Niko and Aldi, corruption was the main reason for their business failures. In Niko's case, corruption directly precluded their making pre-planned and necessary changes to their business, so that it might become profit-making. In Aldi's case, the corruption was indirect, as his competitors evaded taxes, as well as bills for water or electricity bills, by the straightforward means of bribing tax collectors and city officials on a regular basis. So treated, these competitors were able to provide their services at a much lower price than Aldi, who found himself driven off the market.

\section{The founding of a business as an opportunity}

According to the World Bank (2019), Albania has made significant economic progress during the last three decades. Changing economic conditions provide more business opportunities (Baron, 2004, 2006; Cohen \& Winn, 2007; Mainela, Puhakka \& Servais, 2014) that function as pull factors for returning migrants (Richmond, 1984; Callea, 1986). Some of those reported on here decided to return specifically in order to start a business. Recent economic developments in Albania, accompanied by lower taxes, are seen by migrants as representing a good opportunity for a firm to be established, or expanded with a view to earnings being maximised. The case of Klara and her husband offers a good illustration of how important market opportunities can prove in shaping a 
decision to return. Entrepreneurs may make good use of their money if they are able to detect such opportunities (Baron, 2004, 2006).

In Greece, my husband and I worked at home. We had a small family business [printing on canvas]. We did well enough, but my husband - who has a genius mind for business - thought that in Albania we would have the chance to expand our business. According to his research, no one did printing on [tarpaulin] covers for trucks. Thus the demand would be high.

(...) So we returned, and now we have our own business here. (Klara)

Altin, a restaurant chef, was at the outset reluctant to move his business from Athens to Tirana. Although his earnings had been diminished by the debt crisis, he did not know how things functioned on the Albanian market, and was afraid to lose the sense of security he had in Athens. However, in the course of discussions with his friends, usually during summer vacations on visits back to Albania, he became convinced that his earnings would be higher. The Albanian economy was expanding (World Bank, 2017), while the taxes businesses had to pay were much lower than in Greece. In Albania, the corporate income tax rate in 2014 was in fact at 15\% for Albanian and foreign companies established and operating in the country (MFA, 2014). That compared with the $26 \%$ rate in force in Greece (Petrakis \& Xenopoulos, 2014).

We moved here [Tirana] because (...) things looked good [regarding business activity] and the taxes were lower. My friends here [in Albania] always urged me to return. (...) [EventualIy] I followed their advice. (...) My earnings here are higher. (Altin)

For Eli, the idea of having her own coffee shop was always an aspiration. And her work experience in Greece equipped her with the necessary skills and knowledge to achieve this:

When I was a little girl I very much liked the smell of coffee beans that my grandma roasted in our small kitchen. From that time on, I was dreaming of being the owner of a coffee shop where people enjoyed their morning coffee. [Initially] it was just a dream, but it became my objective when I migrated to Greece. There I worked as a waitress and as a barwoman. I learned a lot about how to make a good coffee and how to make people feel comfortable, and also how to manage (...) a coffee shop. I always had in my mind the idea of making some money in order to have my coffee shop. In Greece it was impossible because I worked in the black. I couldn't do my papers because my employers didn't agree to pay insurance. There I needed to invest more money than here, but my status [being undocumented] didn't allow me to gain access to [the required] funding. That's why I opened it here, in Tirana. (...) I had told my relatives who lived here to find for me a place to rent near the center. After they found it, I came to see it (...) and I rented it.

According to Eli, her status as an irregular migrant was the main factor preventing her from becoming an entrepreneur in Greece. Irregularity of status was the source of many problems migrants faced, with legalisation issues having a negative role on their economic integration. They also fuelled other problems migrants faced, such as racism and discrimination. In 1998 in particular, Albanian migrants came to be regarded as the main cause of rising crime rates in Greek society (Pavlou, 2001; Triandafyllidou, 2002; Jordan et al., 2003).

In Greece, we Albanians experienced a lot of racism (...) [the cause of which was] also the policy of the Greek state. It was very difficult for us to find a job or rent a house, because of the negative stereotype of the Albanian migrants constructed by the media and the state. (Pier) Within this last category of opportunity-seeking migrants, there is a small number of returned 
migrants-turned-entrepreneurs who had pre-planned (i.e. before migrating) to set up a business upon their return. Within the theoretical framework of the New Economics of Labour Migration approach, return migration is usually viewed as 'part of an optimal residential location place over the life cycle' (Borjas \& Bratsberg, 1996, p.165), whereas migration is regarded as a means by which future objectives can be fulfilled following return. The idea underlying this approach is that migrants often pre-plan their return. People decide to migrate to accumulate the economic and human capital enabling them to achieve their initial objectives, such as their involvement in new, higher-level activities following return (Thomas, 2008, p.657). In this context, the return would also be conditional upon the presence of opportunities in their country. The Albanian economy was experiencing growth from 1998 onwards (World Bank, 2017), providing many such opportunities for would-be entrepreneurs. As Teli mentioned:

I left Albania because I wanted to see how businesses in Western countries were being run. I wanted to gain expertise and make some money, and then return to Albania and start something of my own. (...) When I met [in Greece] a Greek businessman willing to collaborate with me, I decided to return and start my business [in Albania]. Here the costs of production are lower compared to Greece.

Mira also intended to return and start her own business. After living in Greece for six years, she and her husband came back and opened a minimarket in Tirana:

The return was always part of our future plans. We left the country temporarily. We didn't intend to stay permanently in Greece. We wanted to make money in order to buy a house and start a business here in Tirana. (...) When we found a place that we liked, we rented it and opened our minimarket.

\section{Conclusions}

The study reported here shows that Albanian return migrants' engagement in entrepreneurial activities is influenced by several push and pull factors, depending on the changing circumstances in their country, as well as in Greece. Two categories of returned migrant-turned-entrepreneur can be identified. The first category of returned migrants was pushed into entrepreneurship on account of the need for their financial problems to be overcome. The second category entailed people being pulled towards entrepreneurship by opportunities they identified on the Albanian market. Within this second category there is a subcategory of returned migrants who had pre-planned their return prior to migrating. The timing of their return depended on the right opportunity being present.

More specifically, one of the main factors pushing certain migrants participating in this study to return to Albania was the Greek debt crisis of 2009. This had a severe impact on their employment and earnings. Those who lost their jobs in Greece decided to return to Albania, with the intention of either starting a small business or simply finding a job. Other reasons for returning to Albania were found to be nostalgia for home and relatives, difficulty with achieving family reunification, or even an inability to engage in higher-level activities (such as starting a business) in Greece. However, they also faced economic problems back in Albania, with most returned migrants remaining unemployed for a considerable period of time, and seeing their savings diminish. Even those who managed to find a job were not satisfied with the working conditions. This category of returned migrants did not plan or aspire to become entrepreneurs. Rather, they chose the path of entrepreneurship out of a need to see financial problems overcome one way or another. 
People in this study's other category of returned migrants aspired to become entrepreneurs. They achieved this goal after identifying and seizing the right opportunity in Albania. The growing Albanian market pulled them into returning and investing their savings in businesses in which they had acquired skills in Greece. But many of the returned migrants started their businesses without any knowledge of, or experience relating to, the specific job profile they had in Greece. They found the right niche and did not hesitate to invest. Others were already business owners in Greece, although it was not easy for them to set up in business. The negative image of the Albanian migrant in Greek society, fostered and preserved by the media but encouraged by policies of the Greek government, hindered these migrants' efforts to pursue their economic interests freely. Nevertheless, they succeeded in becoming entrepreneurs, with some deciding to return to Albania and moving their businesses with them. As a result of the Greek debt crisis, taxes increased and the turnover of businesses in general decreased; Albanian migrants saw their earnings diminish. In this environment, Albania appeared to be more business-friendly. Lower taxes, in addition to a generally good economic outlook, functioned as a significant incentive to return.

Within this category of opportunity-seeking migrants, there are some who had pre-planned their return to Albania before migrating. They were highly motivated to succeed as entrepreneurs. Their reason for migrating to Greece was to accumulate enough money and learn how to manage a business. Apart from the fulfillment of these initial intentions, their decisions to return and set up their businesses were also determined by detection of an appropriate opportunity at home.

Both categories of returned migrants-turned-entrepreneurs have faced problems with corruption. However, while most of these businesses endured and continued to operate normally, a few were indeed driven to failure.

\section{References}

Åkesson, L., \& Eriksson-Baaz, M. (Eds.). (2015). The new developers? Experiences of African return migrants. London: Zed Books.

Aliaga-Isla, R., \& Rialp, A. (2013). Systematic Review of Immigrant Entrepreneurship Literature: Previous Findings and Ways Forward. Entrepreneurship \& Regional Development: An International Journal, 25(9-10), 819-844. https://doi.org/10.1080/08985626.2013.845694

Arentz, J., Sautet, F., \& Storr, V. (2013). Prior-knowledge and opportunity identification. Small Business Economics, 41, 461-478. https://doi.org/10.1007/s11187-012-9437-9

Arif, G., \& Irfan, M. (1997). Return migration and occupational change: The case of Pakistani migrants returned from the Middle East. The Pakistan Development Review, 36(1), 1-37.

Baldwin-Edwards, M. (2002). Semi-reluctant hosts: Southern Europe's ambivalent response to immigration. Studi Emigrazione, 39(145), 27-48.

Baldwin-Edwards, M. (2004). Albanian emigration and the Greek labour market: Economic symbiosis and social ambiguity. Journal for Labour and Social Affairs in Eastern Europe, 7(1), 51-65.

Barjaba, K. (2004). Migration and ethnicity in Albania. Synergies and interdependencies. The Brown Journal of World Affairs, 11(1), 231-239.

Baron, R. A. (2004). The cognitive perspective: a valuable tool for answering entrepreneurship's basic "why" questions. Journal of Business Venturing, 19(2), 221-239. https://10.1016/S08839026(03)00008-9

Baron, R. A. (2006). Opportunity recognition as pattern recognition: How entrepreneurs "connect the dots" to identify new business opportunities. The Academy of Management Perspectives, 20(1), 104-119. https://10.5465/amp.2006.19873412

Black, R., \& Castaldo, A. (2009). Return migration and entrepreneurship in Ghana and Côte d'Ivoire: The role of capital transfers. Tijdschrift Voor Economische en Sociale Geografie, 100(1), 44-58. https:// doi.org/10.1111/j.1467-9663.2009.00504.x 
Boccagni, P. (2011). The framing of return from above and below in Ecuadorian migration: A project, a myth, or a political device? Global Networks, 11(4), 461-480.

Borjas, G., \& Bratsberg, B. (1996). Who Leaves? The outmigration of the foreign-born. The Review of Economics and Statistics, 78(1), 165-176. https://doi.org/10.2307/2109856

Callea, A. S. (1986). Different forms, reasons and motivations for return migration of persons who voluntarily decide to return to their countries of origin. International Migration, 24, 61-76. https://doi. org/10.1111/j.1468-2435.1986.tb00102.x

Cassarino, J. P. (2004). Theorising return migration: The conceptual approach to return migrants revisited. International Journal on Multicultural Societies, 6(2), 253-279.

Cohen, B., \& Winn, M. (2007). Market imperfections, opportunity and sustainable entrepreneurship. Journal of Business Venturing, 22(1), 29-49.

Cohen, N. (2009). Come home, be professional. Ethno-nationalism and economic rationalism in Israel's return migration strategy. Immigrants \& Minorities, 27(1), 1-28. https://doi. org/10.1080/02619280902895843

De Soto, H., Gordon, P., Gedeshi, I., \& Sinoimeri, Z. (2002). Poverty in Albania: A qualitative assessment. Technical Paper, 520. Washington, D.C.: World Bank.

Démurger, S., \& Xu, H. (2011). Return migrants: The rise of new entrepreneurs in rural China. World Development, 39(10), 1847-1861.

Desai, S. (2009) Measuring entrepreneurship in developing countries. Research Paper, 2009/10. United Nations University, World Institute for Development Economics Research. Retrieved from https:// core.ac.uk/download/pdf/6235672.pdf

Dustmann, C., \& Kirchkamp, O. (2002). The optimal migration duration and activity choice after re-migration. Journal of Development Economics, 67(2), 351-372. https://doi.org/10.1016/S03043878(01)00193-6

Gedeshi, I., \& King, R. (2018). New trends in potential migration from Albania. Tirana: Friedrich- EbertStiftung. Retrieved from http://library.fes.de/pdf-files/bueros/albanien/15272.pdf

Gubert, F., \& Nordman, C. J. (2011). Return migration and small enterprise. Development in theMaghreb. In S., Plaza, \& D., Ratha, (Eds.). Diaspora for Development in Africa (pp. 103-126). Washington: The World Bank.

Harding, R., Brooksbank, D., Hart, M., Jones-Evans, D., Levie, J., O'Reilly, J., et al. (2006). Global entrepreneurship monitor United Kingdom 2005. London: London Business School, Global Entrepreneurship Monitor.

Hatziprokopiou, P. (2003). Albanian immigrants in Thessaloniki, Greece: processes of economic and social incorporation. Journal of Ethnic and Migration Studies, 29(6), 1033-1057. https://doi. org/10.1080/1369183032000171357

Hatziprokopiou, P. (2006a). Globalisation, migration and socio-economic change in contemporary Greece. Processes of social incorporation of Balkan immigrants in Thessaloniki. Amsterdam: Amsterdam University Press.

Hatziprokopiou, P. (2006b). Migration and changing urban geographies in the European south: evidence from the case of immigrants in Thessaloniki. Migracijske i Etničke Teme, 22, 113-136. Retrieved from https://hrcak.srce.hr/file/8135

Hausmann, R., \& Nedelkoska, L. (2017). Welcome home in a crisis: Effects of return migration on the non-migrants' wages and employment. HKS Working Paper, RWP17-015. https://doi.org/10.2139/ ssrn.2939702

Hessels, J., van Gelderen, M., \& Thurik, R. (2008). Entrepreneurial Aspirations, Motivations, and Their Drivers. Small Business Economics, 31(3), 323-339. https://doi.org/10.1007/s11187-008-9134-x

Hills, G., Shrader, R., \& Lumpkin, T. (1999). Opportunity recognition as a creative process. In P. D., Reynolds, W. D. Bygrave, S., Manigart, C. M., Mason, G. D., Meyer, H. J., Sapienza \& K. G., Shaver (Eds.). Frontiers of Entrepreneurship Research (pp. 216-227). Wellesley, MA: Babson College.

Ho, E. L. E. (2011). "Claiming” the diaspora: Elite mobility, sending state strategies and the spatialities of citizenship. Progress in Human Geography, 35(6), 757-772. https://doi.org/10.1177/0309132511401463 
Ilahi, N. (1999). Return migration and occupational change. Review of Development Economics, 3(2), 170-186. https://doi.org/10.1111/1467-9361.00059

INSTAT, IOM (2014). Return migration and reintegration in Albania 2013. Tirana: Institute of Statistics, International Organization for Statistics. Retrieved from https://albania.iom.int/sites/default/files/ publication/15.\%20Return\%20Migration\%20and\%20Reintegration\%20in\%20Albania\%202013.pdf

losifides, Th., \& King, R. (1998). Socio-spatial dynamics and exclusion of three immigrant groups in the Athens conurbation. South European Society and Politics, 3(3), 205-229. https://doi. org/10.1080/13608740308539554

Jordan, B., Stråth, B., \& Triandafyllidou, A. (2003). Comparing cultures of discretion. Journal of Ethnic and Migration Studies, 29(2), 373-395. https://doi.org/10.1080/1369183032000079648

Kapllani, G., \& Mai, N. (2005). Greece belongs to Greeks! The case of the Greek flag in the hands of an Albanian student In R., King, N., Mai \& S., Schwandner-Sievers (Eds.). The New Albanian Migration (pp. 153-172). Brighton: Sussex Academic Press.

Kasimis, C., \& Papadopoulos, A. G. (2012). Employment and professional mobility of migrants in two local labor markets. In C., Kasimis, \& A. G., Papadopoulos (Eds.). Immigrants in Greece: Employment and Integration into Local Communities (pp. 289-326). Athens: Alexandria [in Greek].

Kerpaci, K. (2007). Social construction of Albanian immigrant stereotype in Greece. A phenomenological approach. Master thesis. Athens: National Kapodistrian University of Athens, School of Law [in Greek].

Kerpaci, K. (2019). Foreigners Natives: Difficulties of integration of Albanian returned migrants in the urban areas of the country. PhD thesis. Athens: University of Harokopio, Department of Human Geography [in Greek].

Kerpaci, K., \& Kuka, M. (2019). The Greek debt crisis and Albanian return migration. Journal of Balkan and Near Eastern Studies, 21(1), 104-119. https://doi.org/10.1080/19448953.2018.1532689

Kilic, T., Carletto, C., Davis, B., \& Zezza, A. (2009). Investing back home: return migration and business ownership in Albania. Economics of Transition, 17(3), 587-623. https://doi.org/10.1111/j.14680351.2009.00357.x

King, R., \& Vullnetari, J. (2003). Migration and development in Albania. Working Paper, C5. Brighton: University of Sussex, Development Research Centre on Migration, Globalisation and Poverty. Retrieved from http://www.sussex.ac.uk/Units/SCMR/drc/publications/working_papers/WP-C5.pdf

Kokkali, I. (2011). From scapegoats to 'good' immigrants? Quaderni del Circolo Rosselli, 3, 161-173. htttps://doi.org/10.1400/215103

Kolvereid, L. (1996). Organisational employment versus self-employment: Reasons for career choice intentions. Entrepreneurship Theory and Practice, 20(3), 23-31. https://doi. org/10.1177/104225879602000302

Kourtovik, I. (2001) Migrants: Between justice and legality. In A., Marvakis, D., Parsanoglou \& M., Pavlou (Eds.). Migrants in Greece (pp. 163-198). Athens: Ellinika Grammata [in Greek].

Krueger, F. N. (2005). The cognitive psychology of entrepreneurship. In Z. J., Acs \& D. B., Audretsch (Eds.). Handbook of Entrepreneurship Research (pp. 105-140). Boston, MA: Springer. https://doi. org/10.1007/0-387-24519-7_6

Kule, Dh., Mançellari, A., Papapanagos, H., Qirici, S., \& Sanfey, P. (2002). The causes and consequences of Albanian emigration during transition: Evidence from micro data. International Migration Review, 36(1), 229-239. https://doi.org/10.1111/j.1747-7379.2002.tb00078.x

Labrianidis, L., \& Hatziprokopiou, P. (2005). The Albanian migration cycle: migrants tend to return to their country after all. In R., King, N., Mai \& S., Schwandner-Sievers (Eds.). The New Albanian Migration (pp. 93-117). Brighton: Sussex University Press.

Labrianidis, L., \& Lyberaki, A. (2001). Albanian immigrants in Thessaloniki: Paths of prosperity and oversights of their public image. Thessaloniki: Paratiritis [in Greek].

Labrianidis, L., \& Lyberaki, A. (2004). Back and forth and in-between: Albanian return migrants from Greece and Italy. Journal of International Migration and Integration, 5(1), 77-106. https://doi. org/10.1007/s12134-004-1003-0

Levitt, P. (1998). Social remittances: migration driven local-level forms of cultural diffusion. International Migration Review, 32(4), 926-948. https://doi.org/10.1177/019791839803200404 
Lianos, T., \& Pseiridis, A. (2009). On the occupational choices of return migrants. Entrepreneurship \& Regional Development, 21(2), 155-181. https://doi.org/10.1080/08985620802176187

Light, I. (2007). Global entrepreneurship and transnationalism. In L. P., Dana (Ed.). Handbook of research on ethnic minority entrepreneurship: A co-evolutionary view on resource management (pp. 3-15). Cheltenham: Edward Elgar Publishing.

Lintner, C. (2018). "If I have to clean, I clean my own shop": Migrant entrepreneurship as a form of emplacement in times of crisis: The example of Italy. Ethnicities, 19(2), 414-432. https:/doi. org/10.1177/1468796818774812

Locke, E. A., \& Baum, J. R. (2007). Entrepreneurial Motivation. In J. R., Baum, M., Frese \& R. A., Baron (Eds.). The psychology of entrepreneurship (pp. 93-112). Mahwah, NJ: Erlbaum.

Mai, N., \& Paladini, C. (2013). Flexible circularities: Integration, return and socio-economic instability within Albanian migration to Italy. In A., Triandafyllidou (Ed.). Circular migration between Europe and its neighbourhood (pp. 42-68). Oxford: Oxford University Press.

Mainela, T., Puhakka, V., \& Servais, P. (2014). The concept of international opportunity in international entrepreneurship: A review and a research agenda. International Journal of Management Reviews, 16(1), 105-129. https://doi.org/10.1111/ijmr.12011

Maritz, A. (2004). New Zealand necessity entrepreneurs. International Journal of Entrepreneurship and Small Business, 1(1), 255-264. https://doi.org/10.1504/JJESB.2004.005655

McCormick, B., \& Wahba, J. (2001). Overseas work experience, savings and entrepreneurship amongst returnees to LDCs. Scottish Journal of Political Economy, 48, 164-178. https://doi.org/10.1111/14679485.00192

Mesnard, A. (2004). Temporary migration and capital market imperfections. Oxford Economic Papers, 56(2), 242-262. https://doi.org/10.1093/oep/gpf042

MFA (2014). A summary of the changes of the tax laws for 2014. Ministry of Finance, Albania. Retrieved from https://financa.gov.al/wp-content/uploads/2017/09/Update-of-Albanian-fiscal-laws-for-2014-2.pdf

Michail, D. (2009). Working here, investing here and there: present economic practices, strategies of social inclusion and future plans for return among the Albanian immigrants a Greek-Albanian border town. Southeast European and Black Sea Studies, 9(4), 539-554. https://doi. org/10.1080/14683850903315029

Michail, D. (2013). Social development and transnational households: resilience and motivation for Albanian migrants in Greece in the era of economic crisis. Southeast European and Black Sea Studies, 13(2), 265-280. https://doi.org/10.1080/14683857.2013.789673

Minniti, M., Bygrave, W. D., \& Autio, E. (2006). Global entrepreneurship monitor, executive report 2005. Babson Park, MA: Babson College, London Business School.

Ní Laoire, C. (2007). The 'green green grass of home'? Return migration to rural Ireland. Journal of Rural Studies, 23, 332-344. https://doi.org/10.1016/j.jrurstud.2007.01.005

Ní Laoire, C. (2008a). Complicating host-newcomer dualisms: Irish return migrants as homecomers or newcomers? Translocations: Migration and Social Change, 4(1), 35-50.

Ní Laoire, C. (2008b). 'Settling back'? A biographical and life-course perspective on Ireland's recent return migration. Irish Geography, 41(2), 195-210. https://doi.org/10.1080/00750770802076968

Nicholson, B. (2001). From migrant to micro-entrepreneur: do-it-yourself development in Albania. South-East Europe Review, 4(3), 39-41.

Nicholson, B. (2002). The wrong end of the telescope: Economic migrants, immigration policy and how it looks from Albania. The Political Quarterly, 73(4), 436-444. https://doi.org/10.1111/1467923X.00498

Nicholson, B. (2004). Migrants as agents of development: Albanian return migrants and micro-enterprise. In D., Pop (Ed.). New patterns of labour migration in central and Eastern Europe. Cluj Napoca: Public Policy Center.

OECD (2014). International migration outlook 2014. Paris: OECD Publishing. https://doi.org/10.1787/ migr_outlook-2014-en

Pavlou, M. (2001). The 'smugglers of fear': racist discourse and immigrants in the press of a potential metropolis. In A., Mavrakis, D., Parsanoglou \& M., Pavlou, (Eds.). Immigrants in Greece (pp. 127- 
162). Athens: Society for Political Thinking "Nikos Poulantzas", Ellinika Grammata [in Greek].

Perunovic, Z. (2005). Introducing Opportunity-based Entrepreneurship in a Transition Economy. Policy Briefs, 39(11). Michigan: The William Davison Institute, University of Michigan.

Petrakis, E., \& Xenopoulos, I. (2014). Greek Tax Overview. Athens: TMS Auditors. Retrieved from http:// tms-auditors.gr/uploads/greek_tax_overview.pdf

Piracha, M., \& Vadean, F. (2010). Return Migration and occupational choice: Evidence from Albania. World Development, 38(8), 1141-1155. https://doi.org/10.1016/j.worlddev.2009.12.015

Puri, S., \& Ritzema, T. (1999). Migrant worker remittances, micro-finance and the informal economy: Prospects and issues. Working Paper, 21. Geneva: Social Finance Unit, International Labour Organization. Retrieved from http://www.ilo.org/wcmsp5/groups/public/---ed_emp/documents/publication/wcms_117997.pdf

Rapoport, H. (2002). Migration, credit constraints and self-employment: A simple model of occupational choice, inequality and growth. Economics Bulletin, 15(7), 1-5.

Reynolds, P., Camp, S., Bygrave, W., Autio, E., \& Hay, M. (2002). Global entrepreneurship monitor global 2002 executive report. Kansas City Mo: Kaufman Centre.

Richmond, A. H. (1984). Explaining return migration. In D., Kubat (Ed.). The politics of return. International return migration in Europe (pp. 227-299). New York, US: Center for Migration Studies.

Schumpeter, J. A. (1974). Capitalism, socialism and democracy (4th edition). London: Unwin.

Shane, S. (2000). Prior knowledge and the discovery of entrepreneurial opportunities. Organisation Science, 11(4), 448-469. https://doi.org/10.1287/orsc.11.4.448.14602

Shepherd, D. A., \& DeTienne, D. R. (2005). Prior knowledge, potential financial reward, and opportunity identification. Entrepreneurship Theory and Practice, 29(1), 91-112. https://doi.org/10.1111/j.15406520.2005.00071.x

Sinatti, G. (2019). Return migration, entrepreneurship and development: Contrasting the economic growth perspective of Senegal's Diaspora policy through a migrant centered approach. African Studies, 78(4), 609-623. https://doi.org/10.1080/00020184.2018.1555310

Smallbone, D., \& Welter, R. (2004). Entrepreneurship in transition economies: Necessity or opportunity driven? Babson College: Babson-Kauffman Entrepreneurship Research Conference.

Thomas, K. (2008). Return migration in Africa and the relationship between educational attainment and labor market success: Evidence from Uganda. The International Migration Review, 42(3), 652-674. https://doi.org/10.1111/j.1747-7379.2008.00141.x

Triandafyllidou, A. (2002). Greece. In J. ter Wal (Ed.). Racism and cultural diversity in the mass media. An overview of research and examples of good practice in the EU Member States, 1995-2000 (pp. 149-170). Vienna: European Monitoring Centre on Racism and Xenophobia, Vienna \& European Research Centre on Migration and Ethnic Relations.

Tsoukala, A. (1999). The perception of the "other" and the integration of immigrants in Greece. In A., Geddes \& A., Favell (Eds.). The Politics of Belonging: Migrants and Minorities in Contemporary Europe (pp. 109-124). Aldershot, Brookfield, Singapore, Sydney: Ashgate.

Tsuda, T. (2010). Ethnic return migration and the nation-state: Encouraging the diaspora to return "home". Nations and Nationalism, 16(4), 616-36. https://doi.org/10.1111/j.1469-8129.2010.00444.x

Turner, S., \& Kleist, N. (2013). Introduction: Agents of change? Staging and governing Diasporas and the African State. African Studies, 72(2), 192-206. https://doi.org/10.1080/00020184.2013.812882

Vathi, Z. (2011). A context issue? Comparing the Attitude towards Return of the Albanian First and Second Generation in Europe. Journal of Mediterranean Studies, 20(2), 343-364.

Vathi, Z., \& King, R. (2011). Return visits of the young Albanian second generation in Europe: Contrasting themes and comparative host-country perspectives. Mobilities, 6(4), 503-518. https://doi.org/10.1 080/17450101.2011.603944

Vullnetari, J. (2007). Albanian migration and development: State-of-the-art review. Working Paper, 18. Amsterdam: IMISCOE.

Vullnetari, J. (2012). Albania on the Move: Links Between Internal and International Migration. Amsterdam: Amsterdam University Press.

Vullnetari, J. (2013). 'Albania: $€ 1$ ' or the story of 'Big policies, small outcomes': How Albania constructs and engages its Diaspora. In M., Collyer (Ed.). Emigration nations: Policies and ideologies of emigrant 
engagement (pp. 25-49). London: Palgrave Macmillan.

Vullnetari, J., \& King, R. (2011). Remittances, Gender and Development: Albania's Society and Economy in Transition. London: GB. I.B. Tauris.

World Bank (2017). Albania. National Accounts Data. World Bank. Retrieved from https://data.worldbank.org/indicator/NY.GDP.MKTP.KD.ZG?end=2017\&locations=AL\&start=1984\&view=chart

World Bank (2019). Albania At-A-Glance. World Bank. Retrieved from https://www.worldbank.org/en/ country/albania/overview

Zografakis, S. \& Kasimis, C. (2014). Greek economy and Immigrants: Yesterday... Today... Tomorrow. In Masourakis, M. \& Gkortsos, Ch. (Eds.). Competitiveness for development: Policy proposals (pp. 381396). Athens: Hellenic Union of Banks [in Greek]. 